\title{
Business Ethics \& Values in Multinational Companies Operating in India: An Innovative Approach
}

\author{
Capt. Dr. Ashok V. Giri \\ MES Garware College of Commerce \\ Ph.D \& M.Phil Research Guide \\ Savitribai Phule Pune University \\ (Maharashtra, India)
}

\begin{abstract}
Elements of Ethical Values include: Ethical values serve the ends of human well-being; The well-being promoted by ethical values is not personal and selfish well-being; No one person's well-being is to be counted as more worthy or valuable than any other's; Ethical values promote human well-being in an impartial way. The main purpose of this research paper is to explore importance of ethical values and business ethics in today's globalized world of high competition and to create awareness about concept and essence of ethical values and business ethics for sustainable progress this globalized world. Research methodology comprises real data - primary and secondary as well based upon Personal Interview Method, Telephonic Interview Method and Questionnaire Method. Research relates to re-exploring the facts which are already with us. Knowledge lies in reviewing and finding new possibilities in information. Research helps in making new innovations to pursue for betterment of our existing awareness. Ethics deal with "what that ought to be". Patrick and Quinn (1997), defined ethics as the study of individual and collective moral awareness, judgment, character and conduct. Business ethics is an art and science of maintaining harmonious relationship with society, its various groups and institutions as well as recognizing the moral responsibility for the rightness or wrongness of business conduct. Values are in inborn within individuals - embedded in individuals. Values differ amongst individuals. Individual values do change temporarily due largely to external influences/forces. Individuals have different sets of values. Values reflect a person's sense of right or wrong. Values lay the foundation in understanding people's attitude and motivation. Values are what we, as a profession, judge to be right. They are more than words-they are the moral, ethical, and professional attributes of character. Values are the embodiment of what an organization stands for, and should be the basis for the behavior of its members. The study emphasizes the essence of ethical values; business ethics and social ethics as backbone in the field of business. Getting information from respondents becomes problematic as we had to interview individuals who had been quite busy to give proper thought to the questions. Indifferent attitude of some respondents could have affected the final findings. Ethical values and Business ethics include Honesty; Integrity; Responsibility; Quality; Trust; Respect; Teamwork; Leadership; Corporate Citizenship; Shareholder Value; social ethics, moral modes, a customer-centric focus, employee satisfaction, customer satisfaction and finally leading to sustainable business in this globalized world. Ethical Values and Business ethics help in satisfying the consumers and customers and employees in maintaining sustainable business in this globalized world. Rationale is a viable approach based on natural values related to the betterment of humanity. It demands honest dealing and proper business ethics which are in the interest of consumers, customers and even employees that lead to sustainable business in this corporate world. Since originality is independent, it depends upon the values that hold the best interest of humanity.
\end{abstract}

Keywords: Ethical Values, Business Ethics, Sustainability, Globalization, Corporate Citizenship, Leadership 


\section{INTRODUCTION}

The path to operationalizing ethical capitalism requires formalizing an introduction to business ethics, grounded in a code of ethics, not just at the top, but throughout the organization. Over time, ethical leadership fosters and sustains enduring corporate cultures that self-govern around corporate values and set forth a code of conduct that meets the highest standards. Now the time has come that managers, CEOs, MDs and owners of business organizations will have to rethink about business ethics which include honesty and respect for company assets; no compromise with quality and competence; embracement of diversity and respect of dignity of fellow employees; respect of customers' needs and values; and so on. Recent global corporate scandals have done long-lasting damage to the reputations of some of our most important civic institutions and businesses. $21^{\text {st }}$ century has opened many corporate ethical scandals that have harmed millions of employees and investors and sent shock waves to the business world. To name a few - Manu Chabra Group for wrecking the fortunes of about half a dozen companies and facing investigation on FERA violations, the Harshad Mehta epic stock scam, ITC's violation of excise laws, the recent UTI scam, the recent Adarsh, Kansal, CWG and 2G spectrum scam. Key constituents - employees, investors, and community members - no longer trust or respect many institutions as much as they once did. Meanwhile, increased transparency and connectivity have enabled greater access to previously private information. The way to thrive in this era of increased public scrutiny is to put an introduction to business ethics training at the core of how corporations conduct business, and by tangibly demonstrating they have nothing to hide. "Doing what's right" represents a sustainable way to create competitive advantage. These traits help in making the business sustainable.

\section{What is Business Ethics?}

The word "ethics" is derived from the Greek ethos, meaning "customary" or "conventional." Ethics is built on good work practices \& what is right; it provides general guidelines on good behavior/conduct of individuals, group, and organization as a whole. Ethics determiners what is right or wrong and choosing what is right. Ethics governs the behavior and conduct of individuals/groups in the workplace. Ethics is one of the hallmarks of a well run Company. Ethics can re assure investors/stakeholders about the Company's approach to its non financial risks. Ethics also help to protect/enhance Corporate/business reputation. Example, corporate image/branding,). To be ethical in the sense of ethos is to conform to what is typically done, to obey the conventions and rules of one's society and religion. Ethics involves a discipline that examines good or bad practices within the context of a moral duty. Moral conduct is behavior that is right or wrong. Business ethics include practices and behaviors that are good or bad.

Ethics is defined as 'a theory or a system of moral values: 'an ethic of service is at war with a craving for gain'.

Ethics may also be defined as 'the branch of philosophy that tries to determine the good and right thing to do; choices regarding right \& wrong,

Ethics (plural, noun): 'the system of beliefs and rules used to judge human action'. Example: 'he is a very honorable person who always acts accordingly to his ethics'.

Oxford Advanced Learner's Dictionary defines the word 'ethics' as "moral principle that govern or influence a person's behavior". Ethics is thus a benchmark of human behavior. The 
conduct of human beings is influenced either by the emotions of life or the actions people perform in different situations. The coordination of action and emotions generates ethics.

\section{Ethical Values}

Values are in inborn within individuals - embedded in individuals. Values differ amongst individuals. Individual values do change temporarily due largely to external influences/forces. Individuals have different sets of values. Values reflect a person's sense of right or wrong. Values lay the foundation in understanding people's attitude and motivation. Values exert major influence on the behavior of an individual/group Values serves as general guidelines in all situations. Values (set of preferences) are said to be the cause and Ethics effect. If one operates in a given instance from a Value emotion within the outward action will tend to be Ethical. Values are those beliefs or standards that incline us to act or to choose in one way rather than another. A company's core values are those beliefs and principles that provide the ultimate guide in the company's decision-making.

Value is defined as a concept that describes the beliefs of an individual or culture. 'A set of values may be placed into the notion of a value system' (Business Dictionary.com).

Values are those things that really matter to each of us ... the ideas and beliefs we hold as special. Caring for others, for example, is a value. (Business Dictionary.com).

The word "values" can sometimes be interpreted with having only to do with "touchy-feely" type things like feelings. However, the idea of values, when it comes to management/strategy, relates much more to practical matters. There is a huge correlation between correct value alignment and success. Values can be defined as those things that are important to or valued by someone. That someone can be an individual or, collectively, an organization. One place where values are important is in relation to vision. One of the imperatives for organizational vision is that it must be based on and consistent with the organization's core values. Values are what we, as a profession, judge to be right. They are more than words-they are the moral, ethical, and professional attributes of character. Values are the embodiment of what an organization stands for, and should be the basis for the behavior of its members. Elements of Ethical Values include: Ethical values serve the ends of human well-being; The well-being promoted by ethical values is not personal and selfish well-being; No one person's well-being is to be counted as more worthy or valuable than any other's; Ethical values promote human well-being in an impartial way.

\section{Need of Study}

In this world of competition and globalization the challenge is to manage the business ethics and ethical values in an appropriate and standardized way. To survive in today's tough competitive business environment and to introduce sustainability in our business, ethical values and business ethics is mandatory to apply in practical form. Right and wrong defined by different people may manifest diverse thinking, motivated by each individual's personal values. Within a work environment, the cultural values that drive business decisions are critical to the organization's credibility with its employees, customers, and shareholders. Today, in business, value is about prioritizing individual and operational values for the workplace and establishing codes of value and codes of conduct that ensures that employee behaviors and the internal systems are aligned with those values which in turn affects the performance of the organization.

Key leadership with appropriate values establishes the moral compass that guides the organization through the complexities of what is right and wrong and how management and 
staff are therefore expected to behave. Critical then, becomes the ability to manage for ethical outcomes - this is values-based management. Values provide the basis for judgment about what is important for the organization to succeed in its core business. Values are traits or qualities that are considered worthwhile; they represent an individual's highest priorities and deeply held driving forces. The need of the study arises for the purpose to make an appropriate balance between the ethical values in business with the profits of its concerned institute.

\section{OBJECTIVES OF THE STUDY}

- To identify reasons why the study of ethics is important.

- To explain the nature and meaning of business ethics

- To identify the status of business ethics and ethical values.

- To realize the contribution of business ethics and ethical values in sustainable development.

- To create awareness about business ethics and ethical values for the benefit of industry, employees, customers, consumers, shareholders and society.

- To study how business ethics and ethical values standards improve productivity, profitability and quality of an organization.

\section{Motivation of Research}

Motivation, in general, is essential in pursuit of every activity. There is $99 \%$ perspiration and $1 \%$ inspiration in motivation. Since, research involves hard labor, persistence and perseverance; these traits can be undertaken only under spirit of motivation. One has to remain internally impelled to pursue knowledge, be patient with difficulties and be ever optimistic to explore and reach some new horizons in the process of research. We personally felt motivated under guidance of our teachers who encouraged us to pursue knowledge for knowledge sake with full interest and thereby enjoy the thrill of research. Our inner urge has always pushed us to remain engrossed in studies and achieve some worthy position in the field of education and research.

\section{Research Limitations}

Getting information from respondents becomes problematic as we had to interview individuals who had been quite busy to give proper thought to the questions. Indifferent attitude of some respondents could have affected the final findings.

\section{Research Methodology}

Research methodology used during the study conducted in this research paper is based upon real data - primary as well as secondary. To conduct this study, exploratory qualitative approach was in practice.

Theoretical frame work was developed from the literature, data collected from the multiple sources of evidence in addition to books, news papers, journals, websites and other professional magazines. A survey was conducted, based on refined questionnaire (reviewed by four experts who had years of experience in the sector of business management) with senior managers, CEOs, and mangers/officers. Apart from these some support personnel (employees of the organizations) were also contacted to make this paper more real and worthy.

\section{ETHICAL VALUES FOR BUSINESS SUCCESS}

Ethics is based on a set of moral and ethical values. These values must be absolute - that is, you must take them seriously enough to override any human rationalization, weakness, ego, or personal faults. When all else fails, you will always look back to these core values to guide 
you. Unfortunately, life is not that easy and there's always disagreement about what values should reign supreme.

\section{Honesty}

The old adage, "honesty is the best policy" is true today more than ever. It's not just lip service.

Employee manuals from most scandalized corporations are likely to contain slogans touting its commitment to honesty. Claiming to be honest in an employee manual is passé. You're either honest or not. Even if you haven't got caught yet, most people know who is and who isn't.

\section{Integrity}

Integrity connotes strength and stability. It means taking the high road by practicing the highest ethical standards. Demonstrating integrity shows completeness and soundness in your character and in your organization.

\section{Responsibility}

Blaming others, claiming victimhood, or passing the buck may solve short-term crises, but refusal to take responsibility erodes respect and cohesion in an organization. Ethical people take responsibility for their actions. Likewise, actions show the ability to be responsible both in the little and big things.

\section{Quality}

Quality should be more than making the best product, but should extend to every aspect of your work. A person who recognizes quality and strives for it daily has a profound sense of self-respect, pride in accomplishment, and attentiveness that affects everything. From your memos to your presentations, everything you touch should communicate professionalism and quality.

\section{Trust}

There's no free ride. Trust is hard to earn and even harder to get back after you've lost it. Everyone who comes in contact with you or your company must have trust and confidence in how you do business.

\section{Respect}

Respect is more than a feeling, but a demonstration of honor, value, and reverence for something or someone. We respect the laws, the people we work with, the company and its assets, and ourselves.

\section{Teamwork}

Two or more employees together make a team. It is a business necessity to work openly and supportively in teams whether formal or informal.

\section{Leadership}

How many hardworking, honest employees have been tainted and led astray by corporate leadership failings? Managers and executives should uphold the ethical standards for the entire organization. A leader is out front providing an example that others will follow.

\section{Corporate Citizenship}

A foundational principle for every company should be to provide a safe workplace, to protect the environment, and to become good citizens in the community. 


\section{Shareholder Value}

Without profitability, there is no company. Every employee should understand how he or she fits into the profitability picture. Everyone's common goal should be to build a strong, profitable company that will last.

\section{Innovative Study}

In this research paper we have discussed empirical study of Cadbury, Nestle, other MNCs (Tata, Sail, Maruti, ONGC, Wipro, Reliance, Infosys, Canon, Johnson \& Johnson, Ford Motor Company, IBM) as follows:

\section{Ethical Values and Business Ethics of Cadbury}

Cadbury is one of the world's largest confectionary manufacturers. Cadbury believes that good ethics and good business go together naturally to produce the best long-term results for all the stakeholders. Cadbury's vision is to be the biggest and the best confectionery company in the world. Its success is sustained by understanding and responding to the needs of consumers, customers, suppliers, colleagues and citizens. Its values are based upon performance, quality, respect, integrity and responsibility, honesty, openness and courtesy. This means everyone in Cadbury acts in an ethical way to protect and promote the company and its reputation among the people and communities it does business with. Cadbury maintains ethical sourcing standards and develops sustainable agriculture programmes such as the 'Cadbury Cocoa Partnership'. Cadbury recognizes its environmental responsibilities. It reduces environmental impact, in particular targeting carbon, packaging and water use, within its broad 'Purple Goes Green' environmental programme.

\section{Ethical Values and Business Ethics of Nestle}

Nestle is the world's leading nutrition, health and wellness company. With over 276,000 employees, the company has operations in almost every country in the world. The people know more by brands and the portfolio covers practically all food and beverage categories, with market leaders like Nestle, DRUMSTICK, NESCAFE, STOUFFERS, KITKAT, Nestle GOODSTART, Nestle PURE LIFE and PURINA, to name a few. Since its founding, Nestlé's business practices have been governed by integrity, honesty, fair dealings and full compliance with all applicable laws. Nestlé's employees worldwide have upheld and lived this commitment in their everyday responsibilities ever since, and Nestlé's reputation remains one of the Company's most important assets today. The Nestle Corporate Business Principles prescribe certain values and principles which Nestle has remained committed worldwide.

\section{Ethical Values and Business Ethics of other MNCs}

(TATA, SAIL, MARUTI, ONGC, WIPRO, RELIANCE, INFOSYS, CANON, JOHNSON \& JOHNSON, FORD MOTOR COMPANY, IBM)

The Tata Group has always sought to be a value-driven organization. These values continue to direct the Group's growth and businesses. The five core Tata values underpinning the way we do business are: Integrity; Understanding; Excellence; Unity; and Responsibility. SAIL (Steel Authority of India) is To be a respected world Class Corporation and the leader in Indian steel business in quality, productivity, profitability and customer satisfaction. Maruti Udyog: We believe our core values drive us in every endeavour: Customer obsession; flexible and first mover; innovation and creativity; networking and partnership; openness and learning. ONGC: To be a world-class Oil and Gas Company integrated in energy business with dominant Indian leadership and global presence. The Spirit of Wipro is the core of Wipro. Spirit is rooted in current reality, but it also represents what Wipro aspires to be - thus making it future active. 
The Spirit is an indivisible synthesis of all three statements: Manifesting intensity to win; Acting with sensitivity; and being unyielding on integrity all the time. Reliance Industries: Reliance believes that any business conduct can be ethical only when it rests on the nine core values of: Honesty; Integrity; Respect; Fairness; Purposefulness; Trust; Responsibility; Citizenship; and Caring. Growth is care for good health. For Reliance Industries: Growth is care for safety; Growth is care for the environment; Growth is conservation; Growth is betting on our people; and Growth is thinking beyond business. Infosys Technologies is a globally respected corporation that provides best-of-breed business solutions, leveraging technology, delivered by best-in-class people and achieves its objectives in an environment of fairness, honesty, and courtesy towards our clients, employees, vendors and society at large. Ethical Values of Infosys Technologies are: Customer Delight; Leadership; Integrity and Transparency; Fairness; and Pursuit of Excellence. Ethical values of Canon include: To foster good relations with customers and communities; to maintain good relation with nations and environment; and to bear responsibility for the impact of their activities on society. Ethical Values of Johnson \& Johnson include: high quality and prompt service at reasonable price with a view to making fair profit; to respect individuality of employees keeping in mind their job security and means of fulfilling family responsibility; Informal communication; Just and ethical action; and to encourage community service. Ford Motor Company's ethical values include: Doing right thing for the customer, people, environment and society; Providing superior returns to our shareholders; and The customer is job 1. Ethical values of IBM include: Respect for individual; IBM anthem; Devotion to customers; Lifetime employment; and Open door program. For IBM Ethics matters because it makes good business sense to "do the right thing". Additionally good corporate ethics results in: Attracting better talent; Retaining employees; Attracting new customers; Retaining customers; Positive effect on Corporate Reputation.

\section{Ethical Values for Managers}

In this research paper we have discussed ethical values for Indian Managers and Western Managers as given below:

\section{Ethical Values for Indian Managers}

Indian managers are moving away from the concept of values and ethics. The lure for maximizing profit is deviating them from the value based managerial behaviour. There is a need for our managers today both in private and public sectors to develop a set of values and believes that will help them attain the ultimate goals of profits and survival and growth. they need to develop the following values: Optimum utilization of resources; Attitude towards work- Managers have to develop the visionary perspective in their work. They have to develop a sense of larger vision in their work for the common good.; Work commitment; and VisionManagers have a long term vision. The visionary managers must be practical, dynamic and capable of translating dreams into reality.

\section{The managers of Indian companies should also develop the following values:}

- Move from the state of inertia to the state of righteous action.

- Move from the state of faithlessness to the state of faith and self-confidence.

- Move from unethical actions to ethical actions.

- Move from untruth to truth.

\section{Ethical Values for Western Managers}

Western managers are highly professionals with excellent analysis power, high professional education and specialization. Western managers follow a proper code of conduct and work in the structured formal atmosphere with no place of modesty in their behaviour. Professional 
efficiency and work disciplines are the conditions under which western managers perform. They consider rules as sacred in their value system. Western value system teaches contractual obligations. Managers honor their contracts. Western managers value principles above its privilege and they consider this as the best strategy to win.

\section{SURVEY RESULTS}

The survey results of the study are as follows:

1) $98 \%$ of the respondents believed ethics and compliance programs are essential to corporate governance.

2) $80 \%$ of those surveyed had developed codes of ethics beyond those required.

3) $90 \%$ included statements concerning the company's obligation to its stakeholders.

4) Research has shown that consumers give preference to companies that adopt CSR practices. According to the 2002 Edelmen Strategy of Survey of Opinion Leaders, $76 \%$ would switch to a company with strong CSR practices, if price and quality are equal to non-CSR competitors. In the same survey, 75\% surveyed reported they would give a CSR company the "benefit of the doubt" if the company were subjected to negative publicity.

5) $52 \%$ of employees observed at least one type of misconduct in the workplace in the past year, with $36 \%$ of these observing at least 2 or more violations.

6) Types of misconduct most observed by employees include:

- $21 \%$ observed abusive or intimidating behavior towards employees.

- $19 \%$ observed lying to employees, customers, vendors, or the public.

- $18 \%$ observed a situation that places employee interests over organizational interests.

- $16 \%$ observed violations of safety regulations.

- $16 \%$ observed misreporting of actual time worked.

- $12 \%$ observed discrimination on the basis of race, color, gender, age or similar categories.

- $11 \%$ observed stealing or theft.

- $9 \%$ observed sexual harassment.

7) $69 \%$ of employees report their organizations implement ethics training.

8) $65 \%$ of employees indicated their organizations have a place they can seek ethics advice. (9) $55 \%$ of employees who observed misconduct at work reported it to management.

9) Reasons Why Employees Do Not Report Observed Misconduct: 18\% of the employees do not know Who to contact; $24 \%$ employees do not care they feel - Someone else would inform; 39\% of the manpower fear no Anonymity; $46 \%$ of the human resources fear Retaliation; and $59 \%$ of the employees think there is no corrective action.

\section{KEY FINDINGS}

1) Ethical Values and Business Ethics help to improve productivity, profitability, quality, public image and brand value of an organization in this world of globalization.

2) Ethical Values and Business Ethics are very effective to achieve sustainable development of an organization.

3) There is limited attention to ethical values and business ethics in India. Business environment in India is not favorable for business ethics and ethical values. There is utmost need to educate the employees as well as managers and even some of the owners, CEOs and MDs also about business ethics and ethical values. 
4) Business must maintain the highest standards of behavior for the benefit of industry, employees, customers and society only with the help of ethical values and business ethics.

The best way of promoting high standards of business practices is through self regulation through ethical values.

\section{CONCLUSIONS}

Lastly in this paper, we conclude that ethical values and business ethics act as a vital tool for removing unethical practices and various scandals that are occurring frequently in this hi tech world of competition and globalization. . Apprehension is that such practices are creeping into general ways of life which are bound to prove detrimental to our social life. There is great need to educate the employees, managers, administrators, CEOs, MDs and even owners of the business organizations regarding ethical values and business ethics along with technical and corporate trainings so as to make our customer and consumers delighted, thus leading to business sustenance and to survive in today's globalized world.

\section{References}

Thomas R. Piper, Mary C. Gentile, and Sharon Daloz Parks, Can Ethics Be Taught?: Perspectives, Challenges, and Approaches at Harvard Business School (Boston, MA: Harvard Business School Press, 1993),

Lisa Jones Christensen, Ellen Peirce, Laura P. Hartman, W. Michael Hoffman, and Jamie Carrier, "Ethics, CSR, and Sustainability Education in the Financial Times Top 50 Global Business Schools: Baseline Data and Future

Joshua Margolis, James Walsh, and Dean Krehmeyer, “Building the Business Case for Ethics," Business Roundtable Institute for Corporate Ethics Bridge Paper ${ }^{\mathrm{TM}}$ series, 2006; available at: www.corporateethics.org/publications.html.Piper, Gentile, and Parks, Can Ethics Be Taught? 7894.

Duane Windsor, “A Required Foundation Course for Moral, Legal and Political Education,” and Laura Hartman and Edwin Hartman, "How to Teach Ethics: Assumptions and Arguments," Journal of Business Ethics Education, no. 2 (2004).

Baker, Wallace R. "A Reflection on Business Ethics”. A commissioned Paper for the UNESCO Forum on Higher Education, Research and Knowledge. Paris, France.

Carter McNamara “Complete Guide to Ethics Management: An Ethics Toolkit for Managers”

Chakraborty, S.K. "Business Ethics in India”. Journal: “Journal of Business Ethics”. Kluwer Academic Publishers, Netherlands.

Cragg, Wesley. "Prosperity and Business Ethics - The case for Corporate Social Responsibility in the Americas". Canadian Foundation for the Americas. 1-896301-59-2.

Habib, Mohsin. "Ethics and Business". University of Massachusetts, Boston.

Hartman, Laura (2004). "Perspectives in Business Ethics”. Burr Ridge, IL: McGraw-Hill.

Harwood, Sterling (1996). "Business as Ethical and Business as Usual”. Belmont, CA: The Thomson Corporation. Hooker, John (2003). “Why Business Ethics?” Carnegie Mellon University.

Jackson, Kevin (2004). “Building Reputational Capital”. New York, NY: Oxford University Press.

Knight, Frank (1980). "The Ethics of Competition and Other Essays” university of Chicago Press. ISBN 0-22644687-5.

"Making Ethical Decisions". The Josephson Institute of Ethics.

McMurrian, Robert C. and Matulich, Erika. University of Tampa. "Building Customer Value And Profitability With Business Ethics”. Journal: “Journal of Business \& Economic Research”, vol. 4, Number 11.

Michael, Michael L. "Business Ethics: The Law of Rules”. Harvard University.

Niles, Nancy J. Concord University. “Business Ethics Education: One Management Educator's Perspective”.Journal: “Journal of College Teaching \& Learning”. Vol. 3, Number 10. 
Newell, Sue. "Business Ethics". Journal: "QFINANCE".

Philips, M. (1992). "Corporate moral personhood \& three conceptions of the corporation". Journal: "Business Ethics Quarterly".

Rosenthal. S. and Buchholz, R. (1999). "Rethinking Business Ethics: A Pragmatic Approach”. New York: Oxford University Press.

Rothman, Howard and Scott, Mary (2004). "Companies With A Conscience”. Denver. CO: Myers Templeton. [27] Satre, Lowell J. "Chocolate on Trial: Slavery, Politics and the Ethics of Business". Ohio University Press.

Seglin, Jeffrey L (2003). “The Right Thing: Conscience, Profit and Personal Responsibility in Today's Business".Spiro Press.

Sen, A. (1993). "Do business ethics make sense?” Journal: "Business Ethics Quarterly".

Trevino, Linda Klebe and Brown, Michael E. "Managing to be ethical: Debunking five business ethics myths".Journal: "Academy of Management Executive". Vol.18, Number 2.

Nestlé Water Website; http://www.water.nestle.com.

Work/life a Balancing Act, Network says: Latest Best Practices report focuses on solutions" release for Network of Executive Women Consumer Products and Retail Industry, http://www.newnewsletter.org/news/index.php

"CEOs as Public Leaders: A McKinsey Survey," http://www.mckinseyquarterly.com 